Multiple interests in urban land: disaster-induced land resettlement politics in Kampala

Colin Marx ${ }^{1}$, Cassidy Johnson ${ }^{1}$, Shuaib Lwasa ${ }^{2}$

1. The Bartlett Development Planning Unit, University College London, London, UK

2. The Department of Geography, Makerere University, Kampala, Uganda

Corresponding author:

Colin Marx

The Bartlett Development Planning Unit, University College London, 34 Tavistock Square, London, WC1H 9EZ, UK.

email: c.marx@ucl.ac.uk

Word count: 8395 


\title{
Multiple interests in urban land: disaster-induced land resettlement politics in Kampala
}

\author{
Abstract \\ One of the actions that many local authorities take in an effort to reduce exposure of informal \\ settlements to disaster risks and the impacts of climate change is to try to move people out of high- \\ risk areas. This is usually enacted through resettlement, relocation or evictions. This article argues \\ that local authorities recognising and validating multiple interests in land offers an innovative \\ advantage to cities in equitably responding to risks, and adapting to climate change. More \\ specifically, we focus on how multiple interests in land in Kampala influenced processes associated \\ with resettlement of people within the context of trying to reduce exposure to disaster risks. In this \\ instance, authorities seeking to resettle people were more inclined to negotiate than impose \\ resettlement and these negotiations opened up the possibilities for more equitable outcomes to \\ emerge, such as staying in their existing communities. The experience of Kampala's authorities offers \\ lessons for other cities confronting resettlement challenges.
}

Keywords: land, property rights, legal pluralism, resettlement, disaster risks, climate change, flooding, Kampala, Uganda

\section{Introduction}

This article draws out how multiple interests in land can be a resource in the ways that cities respond to the need for land resettlement associated with disasters. The article is provoked by experiences in Kampala as it manages approaches to flooding-induced land resettlement associated with climate change. As we reflect on these experiences, we are deliberately contesting the common view that the future sustainable growth of cities depends on the clarification of interests in land, as represented by the exclusive rights of private property defined and enforced by the state. With extreme weather variations associated with climate change exacerbating the risks associated with urban development, this article presents an argument for a reconsideration of property rights in relation to disaster risks. 
There are two parts to the argument of this article. First, situations where there are multiple interests in land are more likely to be equitably aligned in cases of adaptation where the distribution of benefits are widely diffused across a city. However, for more equitable outcomes to be achieved, the relevant authority has to recognise the multiple interests. Thus, the second part of the argument is that this recognition leads to opportunities for negotiation amongst a broader range of stakeholders. In making this argument, our intention is to highlight the role of multiple interests in land in addressing issues of resettlement. We are not arguing that, in themselves, multiple interests (which are typically already highly unequal) will redress issues associated with resettlement. Our claim here is more modest: multiple interests can make a difference to the way resettlement is perceived and negotiated. In the case of Kampala, the need for resettlement was reduced and a broader range of stakeholders were compensated than if there had been a private property regime operating.

In line with wider calls for theorising from the 'south', this example from Kampala demonstrates a framing of multiple interests in land where multiple interests are understood as presenting a situation where there is more than one effective right or claim on a parcel of land and which right or claim will prevail cannot be pre-determined. In relation to the wider applicability of our argument, scholars of legal pluralism have demonstrated that all cities have multiple interests in land in some form or other (Oomen and Durmus 2019; Nuijten 2015; VanderVelde 1993). Far from only being a place where 'best practice' developed in the global North is applied, we show here how Kampala can generate insights into ways of urban development that lead the way for other cities.

We begin by setting out a conventional wisdom that multiple interests in land facilitate and perpetuate forms of urban settlement that increase risk from disasters, and that complicate attempts at resettlement. We offer this as a starting point to anchor our argument in contemporary practical experiences of many planners but also to provide a way to examine some of the key issues that underpin this conventional wisdom. We critique conventional 
notions of private property by adopting a view of property as a social relation. This provides a way to consider multiple interests in land as still constituting property. Consequently, we turn to consider the key issues of property rights and in the process retrieving the value of multiple interests in land as worth consideration in climate adaptation planning. With this theoretical grounding, we examine a flood-risk reducing infrastructural project in Kampala that required resettlement of people in order to construct the infrastructure. In the example, we show how multiple interests, and their recognition by the local authority, reduced the risk of resettlement for people.

\section{Background: multiple interests in land as a facilitating and perpetuating high-risk settlement, and complicating resettlement processes}

Most cities have been established in ways and in locations that, historically, made very different assumptions about the effects of a changing climate. As weather variability associated with climate change is making itself felt, there are a growing number of cities that are experiencing increasing exposure to disaster risks (IPCC, 2012). One of the most prevalent ways in which this increased exposure is being experienced is in relation to settlement patterns. There is a common pattern in most cities that the poorest tend to settle in the areas most exposed to disaster risks. Even in cities that have been planned with some regard to risks, it is typically the poorest that will be located in the low-lying areas, steep slopes or exposed lands (Hardoy et al., 2001). In cities where there has been very little planning or where there is little adherence to formal planning, it is generally the case that poorer people will settle on the land that is perceived to be of the lowest quality, where quality can be measured in terms of exposure to risks of different kinds. Thus, either way, there tends to be a coincidence between exposure to disasters and poorer groups in cities. 
In such contexts, planners and urban managers are confronted with a seemingly impossible problem to solve in a progressive way. On one hand, it is widely acknowledged that the presence of low value (in this case perceived as disaster prone) land offers poorer people an opportunity to access cities and settlement that they would otherwise not have had. In the absence of societies being able to cope with overwhelming processes such as rapid urbanisation, such access is both to the benefit of the people themselves as well as contributing to the city, albeit often sub-optimally in terms of perpetuating forms of exploitation, impoverishment and lower productivity.

On the other hand, such settlement can be highly problematic. For the people concerned, they are exposed to higher levels of disaster and health risks and are likely to be the least able to financially insure themselves against losses or recover from extreme events. For the city as a whole, such settlement can compromise ecosystem features that the city depends on (for example, degrading the flood absorption qualities of wetlands) and/or speed up the degradation of natural features (for example, settlement on unstable slopes prone to landslides) that have effects and a broad range of costs beyond the immediate settlement and on the city as a whole (such as disrupting infrastructure or circulation patterns).

Apparently, either which way planners and urban managers act they can be seen to be regressive. If planners prevent settlement in low value, risk-prone land, poorer people are likely to face even direr situations where they are more at the mercy of landlords and caught up in greater forces of commodified economies than in situations where the rent/payment is likely to be lower and there is some possibility for self-provisioning. If planners do not prevent such settlements then there are likely to be criticisms about why such forms of settlement were allowed and the imposition of greater costs imposed on the city as a whole as 
it pays for the consequences of settlement on (increasingly) disaster risk-prone land. This outcome also being likely to further undermine the authority of planners as having some expertise to guide the future development of the city in an equitable, efficient and sustainable way.

In the light of such difficulties, it is common for the attention to fall on what are seen as multiple, muddled, confusing and/or poorly defined property rights systems. The line of reasoning goes something like this: where property rights are clear (meaning singular and exclusive), it is more likely that they can be recognised, claimed and enforced. Where there can be acknowledgement of other's land rights, ownership and enforcement, planners can discourage poor people from settling on risk-prone land by exercising their right to exclude people from accessing certain parcels of land and encouraging settlement elsewhere. That is, multiple interests in land (as an expression of poorly defined property rights) is justifiably considered as creating the possibility for people to settle in disaster risk-prone areas as well as limiting the ability of planners to discourage such settlements in the first place.

The situation becomes even more complex in the light of the need for adapting to the worsening impacts of disasters due to climate change. Due to changing weather patterns such as heavier rainfall, drought and stronger winds, cities are facing demands to keep the population safe from harm. Choices for adaptation could involve, among other options, investments in risk reducing infrastructure, collective efforts at improvements to service provision, or moving people out of harm's way, through relocation, planned resettlement or eviction ${ }^{1}$. Here again, multiple interests in land create problems for planners. The multiple

\footnotetext{
${ }^{1}$ Resettlement is a major integrated, comprehensive movement of people and families which involves not only new housing and services but also new social and economic relations (Ferris, 2012). Relocation, refers to nonsystematic movements of families or individuals from hazard-prone locations to nearby areas (Ferris, 2012). Eviction is the permanent or temporary removal against their will of individuals, families and/or communities
} 
interests can take the form of either where there is legitimately more than one claim to a parcel of land, and/or that may relate to different rights to the land, and/or that the claims are overlapping to some extent. The implication is that there are multiple relations established between people in relation to the same parcel of land.

However, the multiple avenues available to different people also allow them to play off different interests and thereby evade attempts by one party to remove them from particular locations. In such scenarios, it is easy to reach a stalemate with the planners unable to muster enough authority to counter claims to land made in other registers. And, it may not just be poor people creating a toehold in the city that take advantage of such situations. Richer, more resourced people can manipulate the situation to their advantage too. Similarly, it is possible that one government department (typically that representing industrial development) can manipulate claims to environmentally sensitive locations to trump another (typically environmental management or disaster management). And still, the imbrication of the problems associated with multiple interests in land do not stop there.

Assuming that resettlement has been decided upon by authorities as the way forward, multiple interests in land, in the location where people are going to be resettled from, are extremely difficult and costly to disentangle and adjudicate because they are typically the (robust) result of long, convoluted, contradictory and overlapping histories of socio-political relations. Such claims defy easy interpretation and categorical definition associated with compensatory schemes. Furthermore, disentangling such claims can unravel socially cohesive relations to accentuate or create divisions in neighbourhoods between those who hold

from the homes and/or land which they occupy, without the provision of, and access to, appropriate forms of legal or other protection and with or without state sanction" (The Committee on Economic, Social and Cultural Rights, CESCR, General Comment 7: The Right to Adequate housing - forced evictions (20/05/97). 
different claims and are thus entitled to different forms of compensation. The multiple interests mean that for many people resettlements amount to forced eviction as 'property' is not recognised and compensation that is received does not equate to what they had before.

There are three processes that relate resettlement to multiple interests in land. First, the lack of clarity about property rights facilitates forms of settlement that are exposed to disaster risks (thus bringing the issue of resettlement to the fore). Second, multiple interests in land perpetuate the problem of settlements being exposed to disaster risks because resettlement can be indefinitely suspended by perceived stalemates created through competing (roughly equal) claims to land. And third, even if resettlement is agreed as the course of action by authorities, its implementation is fraught with igniting social and political costs that can quickly balloon beyond any budget allocations for financially compensating those identified as needing resettlement. As a consequence, by the time planners confront issues of actual resettlement, the issues surrounding multiple interests in land are already considered to be a causal factor in their predicament.

But then, 'mutually accepted' resettlement rarely offers an equitable solution either. For example, distinguishing between who has rights to be resettled is enormously complicated with short-term tenants typically losing out (de Sherbinin, 2011). Resettlement processes have a wide and significant range of pre- and post-relocation costs (Nikuze et al. 2019; Ferris 2012). The destinations for relocated people are typically less well-located, serviced and integrated than their points of origin. The result being that their new risk of exposure to poverty dwarfs the original risk of exposure to disaster related risks (Kita, 2017). And, the legitimacy of claims to resettle people from risk-prone locations can be undermined when 
higher-yield land uses occupy vacated land to take advantage of locational access to centrality and/or infrastructure (Correa, 2011).

Here, we need to declare that we are motivated by a commitment to minimise resettlement unless it is demonstrably necessary and that it clearly benefits those affected. This declaration is important to foreground because it informs the argument we are making in the article. Thus, how to address the plight of decision-makers? They appear caught between: a) the symptoms of land settlement in high-risk locations caused by multiple interests of land, yet, b) constrained by the effects of multiple interests in land, and if c) authorised to proceed with resettlement, intervening in social relations that can easily unravel to the detriment of the vulnerable. In addition, resettlement is itself a cost imposed on those least able to afford it. In such a light, how can our claim, that multiple interests in land offer an advantage to cities adapting to climate change, be sustained? How can multiple interests in land offer an advantage when it is implicated in causing problematic settlement, perpetuating settlements with high exposure to disaster risk and creating 'solutions' of resettlement that typically have overall adverse consequences for poor people that are resettled?

Two theoretical points are flagged from our analysis of Kampala. ${ }^{2}$ The first point relates to why multiple interests could be advantageous in a context of cities adapting to climate change at multiple scales. Property rights have been neglected in broader debates about how they shape the responses to adapting to climate change in cities (Arnold 2014; Mulvaney

\footnotetext{
${ }^{2}$ Our analysis builds on research project: "Reducing relocation risk in urban areas" (February 2015December 2016). In the initial research we conducted 11 semi-structured interviews with policymakers in Kampala and 70 in-depth interviews with household heads and small enterprise owners affected by the resettlement plans related to the infrastructural upgrading process. Through an open coding of the interview transcripts we identified that multiple interests in land were a key issue explaining why people continue to settle in flood prone areas. The current article builds on this analysis and reflects on it from an angle of property rights and the equity of climate change adaptation.
} 
2014). Notably however, Doremus (2012) has pointed out that climate change calls for changes towards 'weaker' (an example of which would be multiple interests in land) rather than stronger individual exclusive property rights. On one hand this is because strong individual property rights have been observed to encourage individuals to believe they could pass the risks of increased exposure to hazards onto others (usually the city or state). This is likely to increase the overall costs of adaptation. On the other, the gains from adaptive change are likely to spread over large parts of cities, while the adaptation costs will be sharply concentrated on individuals thus discouraging the collective action needed (Doremus 2012). The implication of this legal perspective is a significant corrective in the light of current policy trends seeking to promote individual private property rights.

The dominant policy trend seeks to clarify and strengthen statutorily-backed private property rights (Giddings 2009; Republic of Uganda 2013) despite calls by legal pluralists to validate multiple systems of law. This is understood to stimulate the effective functioning of land markets which in turn promote the most effective use of land and greater overall societal well-being (Deininger 2003). A key foundation for this policy is the theoretical understanding of private property being at the apex of the evolution of property rights systems (Platteau 1996). Theoretically, there are strong incentives in any society to create the conditions for private property, which then offers substantial benefits to society as a whole. These incentives are almost impossible to override and over time, 'weaker' rights will inevitably give way to exclusive private property rights.

\section{Repositioning private property}


The notion that statutorily defined private property is the apex of property rights is so hegemonic that unless we can show that there are alternative ways of imagining property rights, planners will always be operating with a view that multiple interests in land are somehow inferior versions. If multiple interests are seen as inferior then they cannot sustain the claim that they might offer advantages. Critics will justifiably point out that property rights that are in transition to something else can hardly offer a feasible platform to inform adaptation strategies.

Retrieving the idea that less strong individual property rights are likely to be more equitable in adapting to climate change, notions of multiple interests in land need to be repositioned in relation to private property so that it is possible to consider a system of multiple interests in land to be valuable in their own right. There are two aspects that need to be addressed: first, that the best form of property rights is statutorily defined and enforced private property rights and second, that there is an in-built tendency for property rights systems to evolve in this direction. Both of these aspects can be shown to rest on a particular set of assumptions.

For many, property is a self-evident and universal category. It has the quality of describing a relation between people and a thing of value. People who hold property are called owners. It is these self-evident and universal qualities that is part of its appeal (Mitchell 2002). The objective qualities of property are presented as divorced from local context - as somehow external to the messiness of local politics and processes and, simultaneously, able to connect different regions of the world into a common system that can generate and unlock value.

Associated with this view, is a particular idea of how property rights evolve. The theory of the evolution of property rights is commonly traced back to Demsetz (1967). This theory 
predicts that as land (in this case) increases in value, it becomes worthwhile to engage in processes that exclude others so that the benefits can be privately enjoyed. Over time, the benefits have come to be considered primarily in a relatively narrow juridical-economic sense. In this economic analysis of costs and benefits, it is argued that, the best way to protect a land resource and realise its value (ultimately also for the greater good of society) is to promote private property rights. Only private property rights will induce behaviour that makes the best use of land.

This view of the evolution of property rights gives rise to the promotion of the dominant policy guidelines referred to above. Apart from the ways in which notions of private property legitimate a particular kind of political role for the state, the theory suggests that the state should take steps to individualise property rights in a clear register that is publicly available and which settle, clarify, and purify property rights so that private property can be considered as a singularity (Blomley 2004). What is important to note at this point is that scholarship and policies on urban land resettlement tend to take this approach to urban property rights, and their evolution, for granted. Thus, resettlement is about recognising particular rights of ownership and promoting the attainment of property rights in the place of resettlement. While the literature on managing disaster risk through resettlement considers land rights as a central issue, there is still room for important nuance in the ways of understanding the messiness and contradictions of property rights and how this influences resettlement processes (Correa 2013; Ferris et al. 2017; Couldrey and Herson 2015; OliverSmith and de Sherbinin 2014).

\section{Property as a social relation}


Yet, there are other perspectives that interrogate the self-evident and universal claims of private property. In these perspectives, property is a social relation between people in relation to something of value (Hunt 1998; Singer 2000). In effect, an agreement between people creates 'property' and the systems of rights and claims that are needed to define, protect, and enforce these. An item is not valuable because it is property. It is property because it is valued. Within the multitude, diversity and density of different social relations that make up cities and ways in which these are valued, it is easy to see how the claims that property rights are self-evident and universal can quickly be interrogated.

In relation to the evolution of property rights themselves, it is clear that the trajectories particularly in African cities - are far from the theoretical predictions. For example, Platteau (1996) noted that property rights systems have not converged on a trajectory of private property and that attempts to stimulate investment does not depend on higher forms of private property. In the intervening period, little has changed in Kampala and not least because such views fail to acknowledge how political interests are imbricated in the development of property rights.

The concept of multiple interests in land that we deploy in this article emerges from the notion of 'open access' property rights elaborated by Fitzpatrick (2006). Fitzpatrick develops an understanding of open access as a situation where there are multiple claims to land and no one party's claims are sufficient to completely exclude the other. This situation arises from "polynormative, multi-layered, and incomplete assertions of exclusionary property rights" (Fitzpatrick 2006, 1046). It is important to specify here that 'open access' does not mean that 'anything goes' or that anybody can have 'access' to land, but that there are specific multiple interests in land that are historical, usually hard-won, bitterly defended, and socially defined. 
This view is useful because it provides an immediate focus on property rights. Although, in its definition it remains implicitly tethered to the hegemonic view of private property and its characteristics. Therefore, we salvage the multiplicity yet explicitly eschew the anchoring to exclusion as the defining characteristic of only private property. Instead we want to look for multiple forms of exclusion afforded by a notion of multiple interests in land.

\section{Moving to Kampala...}

Kampala, as a city, faces a struggle to deal with flooding. The location, topography, and settlement patterns have resulted in the city being particularly susceptible to hydrometeorological changes (Lwasa et al. 2009; UN-Habitat 2013). Its position within Indian Ocean tropical weather systems and proximity to Lake Victoria has meant that rainfall has increasingly become variable with extremes associated with climate change.

Topographically, the city is built on hills and wide wetlands that either drain south into Lake Victoria or north to Lake Albert. These wetlands perform important eco-system services to the city. Over time, poorer people have settled in the floodplains compromising their ecological functions (Waters 2013). And, not just people because the state has used the floodplains to build infrastructure and historically had an industrial policy that promotes the establishment of industrial land in the floodplains/wetlands. It is widely acknowledged that the exposure to risk of flooding is disproportionately borne by those living in the floodplains.

Kampala is also growing very rapidly. The population of the Greater Kampala Metropolitan Area is estimated at a little over 3 million and is projected to grow to some 5 million in the coming decade and to exceed 10 million within a generation. This is due to ongoing rapid population growth of $4.5-5 \%$ per annum (KCCA, 2012). And, if in-migration is to accelerate over the coming generation the city's population may well significantly exceed 15 million by 2040 (KCCA, 2014: 21). In informal settlements, it is evident that, as the city develops it will 
need to allow the floodplains to perform their eco-system function of absorbing excess water, retaining and filtering it. It will also need to find some way to deal with the existing (and future 'uncontrolled' growth of) settlements in the floodplains.

Ours is not the first study of the relationships between environmental degradation, the pressures of urbanisation and the constraints of underlying law in Kampala. Nuwagaba (1996; 1997) examined the relationships concluding that multiple interests in land (expressed as a dualism) was counter-productive and serving the "interests of very few relative to the tens of thousands currently living in bad housing conditions and poverty" (Nuwagaba 2006, 164). Another line of critique of multiple interests comes from those wanting to stimulate formal land markets (Giddings 2009; Irumba 2015). Others, such as Nkurunziza $(2007,2008)$ and Lwasa (2010), suggest that the multiple systems should be seen in a more positive light as an accommodation between different interests that afford a wide range of possibilities that create the diverse range of opportunities for a city to develop.

Despite these differences, what has remained consistent is an oft-heard analysis from local government policy makers that in the midst of multiple interests, private property somehow lies outside their domain of control. Quoting a Kampala city planner in 2002, Nuwagaba $(2006,161)$ writes “...we are not lacking the human capacity or legislation to demolish [informal settlements], but these dilapidated housing structures belong to private people you may find it difficult to touch $[\ldots]$ they belong to private people who are powerful in their own way and there is nothing you can do to their private properties". In the intervening period between then and when we conducted research in Kampala in 2016, it appears little has changed in this respect. 
A senior Kampala Capital City Authority (KCCA) planning official echoes the point noting "that much of this land where the drainage channels are, some of it is private land, or land that KCCA as a government institution doesn't have full control over. It's in private hands, so we cannot... much as it's designated maybe as a wetland or drainage channel, when it comes to land rights, it becomes sometimes challenging to immediately enforce, or limit the kind of usage that is taking place". Such an understanding is also often coupled to the exorbitant costs of compensating people for their 'private property'. ${ }^{3}$ However, both quotes indicate that understandings of private property rights are significant in dealing with Kampala's development. They start to substantiate our earlier theoretical point of needing to revisit the role of notions of private property in relation to climate change can be envisaged.

Part of what is at stake here, is the understanding of private property that is being deployed. A clue is in planners' recognition that (exclusive) property rights are being created, but we argue that while planners seem to be interpreting all claims to property in the light of statutorily defined private property, in fact their actions suggest that they already see 'private property' as taking multiple forms and being constituted by multiple interests. That is, while urban planners and managers represent property as if it is conventionally-defined private property, when confronted with a challenge of reducing disaster risk they have acted (un/intentionally) with a different understanding. Their actions belie a representation of property as exclusionary in order for a claim to be considered as property and reflects a view that there are many forms of property (Macpherson 1992). Rather than being seen as stronger or weaker forms of statutorily defined private property, these diverse forms work differently within specific configurations of multiple interests. In the ability to see the potential offered

\footnotetext{
${ }^{3}$ In Uganda, resettlement occurs through financial compensation due to eviction. That is, the process of resettling is left to the discretion of the evictee with their compensation.
} 
by the characteristics of diverse forms of property lies the advantage of multiple interests in land to cities adapting to climate change.

\section{Multiple interests in land in Kampala}

Uganda (and especially Kampala with its location overlapping the Buganda Kingdom) has evolved a complicated land property rights system with contradictory and overlapping interests created by successive political developments (Nkurunziza 2007; Médard and Golaz 2018; Lwasa 2010). Woven through these complications are multiple interests as constituent, expression, motivation and threat are party political interests. Thus, land is tied into electoral politics in complex ways (Meinert and Kjær 2016) and the ways in which it is politicised means that it is important to have multiple channels to contest adverse trends and/or access opportunities (Golooba-Mutebi and Sjögren 2017; Goodfellow 2013). As threat, not enforcing land administration regulations (including property rights) is functional to a political elite who depend on keeping interpretations of law open as a way to exploit land as a political resource (Kjær 2017; Byerley 2013). In this context, thinking about property rights always also means thinking about politics and we return to this point in the conclusion.

The complex history of land in Kampala has resulted in 5 different ways, with varied distributions, in which land is associated with different entities. In order of size of land area: informal subdivision on mailo land (45\%), customary land controlled by the Buganda Land Board (27\%), public land under the Kampala District Land Board (15\%) and Uganda Land Commission (10\%) and freehold land held by the Roman Catholic and Anglican churches (3\%) (Nkurunziza 2007, 171). We cite these distributions to give a sense of the magnitude of the different ways in which land is ultimately held. The exact distribution is not as important as the diversity and because layered over these underlying distributions of association are many different statutory and 'every-day' ways of holding land created by tenancies, sub- 
tenancies and various informal arrangements that create user rights subsequent or consequent on this.

In statutory terms, the Constitution of the Republic of Uganda and subsequent land laws creates property rights that can be held by individuals as well as held in trust for a defined group of users or the commonwealth of the country. ${ }^{4}$ The Constitution of Republic of Uganda Art. 237 (2) (b) and the National Environment Act 1995, create particular property rights that should prevent the land that is inundated by water from being used by land uses that cause the wetland to degenerate or which worsen flooding. The Buganda Land Board applies customary law to land under its control in Kampala. Thus, any one parcel of land in Kampala could potentially have multiple interests - with none able to completely exclude the interests of the other - of the national state (as a state as well as through various derogations to different ministries), the National Environmental Management Agency, the KCCA and the Buganda Land Board. Into this mix, we could also add the 'project law' of the World Bank that attaches legal conditionalities to the projects it is involved in such as the infrastructure project we will discuss below.

The multiplicity of interests is constituted by different concepts of land rights and how they emerge. Access to land and property exist within a regime of rights in which the relationship of an individual to the group and of different groups to each other and the state is critical. An example of this is in Kampala in relation to customary ownership which overlaps both official ${ }^{5}$ and private mailo land. Because land is held in trusteeship under customary law, through time, many claims to property rights have been entrenched through bequeathing,

\footnotetext{
${ }^{4}$ This in itself creates ambiguities.

${ }^{5}$ Official mailo is land originally allocated to the Kabaka and royalty at the time of the 1900 Buganda Agreement.
} 
kinship, caretaker roles and converted into bonafide occupancy enshrined in the constitution. Theoretically, even when private rights are defined on land, the customary rights overlap creates multiple interests and the exclusive rights are limited by this diversity.

The concept of land rights is an expression of the values to which a society adheres or aspires. Regimes of land rights vary enormously from those, on one hand, which regard land in trust to be protected for future generations, to those on the other hand, which regard rights as a commodity to be enjoyed or exploited like any other commodity. We describe three different kinds of property (in no particular order) constituted by multiple interests in land and sustained by the diverse social mechanisms that they are caught up in, and which are relevant in the example we elaborate below. ${ }^{6}$

The first is bonafide occupants or licensees or squatters and originates in squatting, land invasion, or other processes of illegal plot occupation and development. Multiple interests emerge because such occupations are unlikely to be strong enough to override underlying property rights. No statutory rights are accorded to this category though in practice residents may occupy their plots for many years and use them for a variety of purposes. Where adverse possession consolidates claims the multiple interests may change and discernible transfer rights may accrue so that parcels of land acquire sufficient value in an active market. This is common in many wetland areas in Kampala that are considered public land with perceived rights to occupy and a right for compensation if the state acquires the parcels for development or to install infrastructure to reduce disaster risks.

\footnotetext{
${ }^{6}$ There is a fourth kind of property constituted by multiple interests that is communal or co-operative ownership. We do not discuss this further because it was not a property right encountered in the example discussed below.
} 
The second is lawful occupants and represents land parcels where some of the interests arise from official recognition (but not including forms of land registration). Again, these rights have emerged over time, sometimes by the active efforts (and interests) of residents, developers and local politicians. It may be expressed or perceived through the provision of improved infrastructure and public facilities. The continued settlement of Buganda land and subsequent registration sometimes with a title but often without a title is an example of this layer of rights. The recent introduction of land titles for Buganda land is causing more mixing of people with and those without official recognition. In such contexts multiple interests are sustained because the costs of achieving more exclusive rights are prohibitive to some. However, where actors seek to contain interests in land, these may open up again where the increasing value of land creates conflicts (Rakodi and Leduka 2004) with the consequence that multiple interests are sustained.

The third kind of property is characterized by occupancy and use rights and could be held by registered landowners. In this case, multiple interests include a compromise between full, formal title and de facto security and are usually intended to retain long-term control over land by the occupiers. Where land has been nationalized, use rights or occupancy permits are granted to residents. But these forms can also be granted by private individuals or institutions with a view to maintain the ownership over land. This again is exemplified by Buganda land and the settlement of reference in this study has substantive chunks of Buganda land. These multiple interests are sustained because the capacity of different groups can be considered more or less the same.

What we have sought to demonstrate in this section is that multiple interests in land do not mean instability and that one system (the statutory) is not necessarily a dominant referent in 
people's everyday lives, simply because it is commonly represented as being theoretically in a supreme position in a hierarchical understanding of property rights. Thus, it is that forms of exclusion to resources in land can co-exist with multiple interests in land. Indeed, we might even think of the multiple interests making exclusion possible or necessary. We are pointing out that just because 'exclusion' is not complete (in a statutorily defined private property sense) does not mean that clearly understood rights to land do not exist. It is in the multiple connections, through which these rights must be agreed, that negotiation can be started.

\section{Infrastructure, flood risk and resettlement}

It was in this context that agencies including the KCCA and the Ugandan Ministry of Works with the support of The World Bank and other multilateral donors developed the Kampala Institutional and Infrastructure Development Project (KIIDP) Phase 1. The project involved roads and highways improvements, flood protection infrastructure and reforms to subnational government administration - principally the Kampala City Council. ${ }^{7}$ The focus of this article is on the flood protection infrastructure in the Lubigi catchment area and in relation to the Bwaise III area. The confirmation of funding allowing the project to be implemented was based on many different studies stretching back to 1996 . One of these feasibility studies was the Resettlement Action Plan (RAP) (Geomaps Africa et al. 2006) developed to manage how to approach the resettlement of people that the implementation of drainage channels and a 3 metre wide buffer on either side of the channel would require.

\footnotetext{
${ }^{7}$ The Kampala City Council was changed into the Kampala Capital City Authority through the Kampala Capital City Act (2010).
} 
The obligatory resettlement plan identified the following categories of rights as eligible for compensation: registered land owners with either leasehold or private mailo land titles; bona fide occupants; lawful occupants; licensees; and squatters. ${ }^{8}$ What is important to note is that there are two levels of multiple interests present in this list. First, that there are multiple categories of interests and second, that each one of the categories is itself an expression of a multiple interest. For example, even 'registered owners' on mailo land (in wetlands) have coexistent interests from the Kabaka, the National Environmental Agency, the national state (through the Constitution) and KCCA's planning and land administration regulations. Indeed, that these multiple interests can also 'overlap' is recognized by the RAP (Geomaps Africa et al. 2006, 65).

The RAP initially identifies 168 household entities as being affected and requiring compensation. However, the financial cost of recognizing these multiple interests mean that further negotiation with the rights holders are required. The RAP immediately revisits the design of the infrastructure to find ways to minimize the impact and suggests the timing of eviction can be delayed such that people can harvest crops. After these revisions, the number of affected household entities is calculated at 67.

In a project as complex as KIIDP Phase 1, there are, of course, many reasons why the number of people resettled could have been reduced and we are not arguing that multiple interests in land are the only reason. Other reasons, for example, are that the authorities were desperately trying to keep compensation costs down. Or, that the authorities had already concluded that the wetland in Bwaise was so degraded that it was not worth trying to rehabilitate it and thus,

\footnotetext{
${ }^{8}$ The source of multiple interests in land is interesting in itself. The possibility that rights for squatters are recognised was created by the World Bank's Policy on Involuntary Resettlement OP/BP/4.12 and not by Ugandan statutory law.
} 
it was not so imperative that people were evicted. Or, that, because it was a linear construction project, affected people could shift backward and squeeze onto a smaller parcel of land, thereby remaining on site. There is also the recognition in the RAP that eviction through resettlement is extremely disruptive in both a social and economic sense and regressive and therefore to be minimized as much as possible. These, and probably more, as yet undocumented, reasons contributed to reduce the need for resettlement. However, more fundamental than most are the multiple interests in land. Without these there would neither be such high initial compensation costs, nor the need to take into account as many households and their associated social and economic links, and as a whole (given the greater scale of impact) the need to look for broader solutions such as complementary drainage systems and upstream design implications.

Moreover, without their recognition and consequent need for negotiation, the resettlement process would have looked very different - with everyone apart from registered owners losing out. This recognition meant that "information from local leaders, elders and other residents will be used to confirm ownership" (Geomaps Africa et al. 2006, 55) where records were overlapping or unregistered by the state. Here we see the multiple interests in land in Kampala arguably made it more likely for the state to find climate adaptation solutions that allow it work within the existing multiple interest system, without imposing strong controls that would disrupt the status quo. We observe that this system potentially enabled a more just way of managing the risk posed with flooding and climate change in Bwaise, because it pushed the state to find ways of dealing with the issues without evicting people or making large-scale sweeping changes. 
While people displaced by the infrastructure in Bwaise found the process and amount of compensation unsatisfactory (delays due to resolving compensation meant the project needed to be extended by two years), far fewer have been resettled than would have been if initial resettlement plans had been implemented. This is very different to cities in neighbouring countries where the resettlement does not appear to recognise multiple interests in land despite their existence. For example, cities such as Kigali (Nikuze et al., 2019), Mzuzu (Kita, 2017), and Dar es Salaam (Kironde, 2016) are also characterised by multiple interests in land and yet the resettlements have not recognised multiple interests in land as being relevant. Thus, it appears that the existence of multiple interests in land, and their recognition, means that the local state has little choice but to act in a way that is more supportive of people with different rights to the land than would otherwise be the case.

The example from Kampala shows how the resettlement process has been 'negotiated,' rather than just implemented by authorities. The actions that are attentive to a multiplicity of interests in land stand in contrast to a dichotomous discursive representation of property as 'private property' that is untouchable as it automatically grants exclusivity versus claims that cannot be recognized as property.

\section{Conclusion....and moving from Kampala}

In this article, we have argued that the multiple interests in land in Kampala offer the city an advantage in adapting more equitably to climate change. This is because, when multiple interests are not seen as a deficient version or kind of property rights in transition to private property but recognised as valuable in themselves, they can offer a basis for thinking about more equitable change. This means promoting recognition and that more attention is needed 
to how they are evolving in themselves and not in relation to some template of private property to make sure we maximise the advantages.

The inherent need to engage with others in a multiple interest system provides a stronger basis for negotiation and understanding of competing needs in land. This corresponds to the legal observation that adapting to climate change is likely to fare better where interests in land are more distributed and multiple. Our analysis shows that Kampala's planners and urban managers are acting with a far more nuanced understanding of property than 'western' theory would allow and which other cities could do well to attend to in deliberating more equitable responses to resettlement in relation to disaster risk. In effect, we are validating the already nuanced actions of planners and urban managers in Kampala who work with forms of exclusion that can co-exist with multiple interests. They recognise that the exclusionary qualities of property are always already shaped by multiple interests: where 'exclusion' is understood, first and foremost, as a respect for people's living and working space. In such understandings, multiple interests are precisely a way of connecting to different processes in the city and their politics.

\section{Bibliography}

African Union. 2009. Convention for the Protection and Assistance of Internally Displaced Persons in Africa (Kampala Convention). Addis Ababa, African Union Commission.

Arnold, Craig Anthony. 2014. "Resilient cities and adaptive law." Idaho Law Review 50 (2):245-64. Blomley, N. 2004. Unsettling the city: Urban land and the politics of property. New York: Routledge.

Byerley, Andrew. 2013. "Displacements in the name of (re)development: the contested rise and contested demise of colonial 'African' housing estates in Kampala and Jinja." Planning perspectives 28 (4):547-70. 
Couldrey, M. and Herson, M. 2015. Disasters and displacement in a changing climate. Forced Migration Review, Issue 49, May 2015.

Deininger, K. 2003. Land policies for growth and poverty reduction. Washington DC: The World Bank.

Demsetz, H. 1967. "Towards a theory of property rights." The American Economic Review 57 (2):347-59.

Doremus, Holly. 2012. "Climate change and the evolution of property rights." University of California Irvine Law Review 1 (4):1091-123.

Ferris, E. (2012). Protection and planned relocations in the context of climate change: UNHCR Geneva.

Ferris, E. et al. (2017) A Toolbox: Planning relocations to protect people from disasters and environmental change. Brookings and UNHCR. Available from: (https://isim.georgetown.edu/Planned-Relocations

Fitzpatrick, Daniel. 2006. "Evolution and chaos in property rights systems: The Third World tragedy of contested access." The Yale law journal 115:996-1048.

Geomaps Africa, Delta Partnership, Interface Consulting, and RESCO. 2006. "Resettlement Action Plan. Volume 1. Kampala Institutional Infrastructure Development Project (KIIDP)." In, 161. Kampala: Republic of Uganda: Ministry of Local Government and Kampala City Council.

Giddings, S.W. 2009. "The land market in Kampala, Uganda and its effect on settlement patterns." In. Washington, D.C.: International Housing Coalition.

Golooba-Mutebi, Frederick, and Anders Sjögren. 2017. "From rural rebellions to urban riots: political competition and changing patterns of violent political revolt in Uganda." Commonwealth \& Comparative Politics 55 (1):22-40. doi: 10.1080/14662043.2017.1248215.

Goodfellow, Tom. 2013. "The clash of institutions: traditional authority, conflict and the failure of 'hybridity' in Buganda." Commonwealth and comparative politics 51 (1):326.

Hunt, R. C. 1998. "Properties of property: Conceptual issues." In Property in economic context, edited by R. C. Hunt and A. Gilman, 7-27. Lanham, Maryland: University Press of America.

Irumba, Richard. 2015. "An empirical examination of the effects of land tenure on housing values in Kampala, Uganda." International Journal of Housing Markets and Analysis 8 (3):359-74.

Kjær, Anne Mette. 2017. "Land governance as grey zone: the political incentives of land reform implementation in Africa." Commonwealth \& Comparative Politics 55 (4):426-43. doi: 10.1080/14662043.2017.1272876.

Lwasa, Shuaib. 2010. Urban land markets, housing development and spatial planning in subSaharan Africa. The case of Uganda. New York: Nova Science Publishers.

Lwasa, Shuaib, C Koojo, F Mabiriizi, P Mukwaya, and D Sekimpi. 2009. "Climate change assessment for Kampala, Uganda. A summary." In. Nairobi: UN Habitat.

Macpherson, C. B. 1992. Property, mainstream and critical positions. Toronto: University of Toronto Press.

Médard, Claire, and Valérie Golaz. 2018. "Entwined values: protecting and subdividing land in Buganda." Critical African Studies 10 (1):47-66. doi: 10.1080/21681392.2018.1491802.

Meinert, Lotte, and Anne Mette Kjær. 2016. "'Land belongs to the people of Uganda": politicians' use of land issues in the 2016 election campaigns." Journal of Eastern African Studies 10 (4):769-88. doi: 10.1080/17531055.2016.1274251. 
Mitchell, T. 2002. Rule of experts: Egypt, techno-politics, and modernity. Berkeley: University of California Press.

Mulvaney, Timothy M. 2014. "Progressive property moving forward." The Circuit (65).

Nikuze, Alice, Richard Sliuzas, Johannes Flacke, and Martin van Maarseveen. 2019.

"Livelihood impacts of displacement and resettlement on informal households - A

case study from Kigali, Rwanda." Habitat International 86:38-47. doi:

https://doi.org/10.1016/j.habitatint.2019.02.006.

Nkurunziza, E. 2007. "Informal mechanisms for accessing and securing urban land rights: the case of Kampala, Uganda." Environment and Urbanization 19 (2):509-26.

. 2008. "Understanding informal urban land access processes from a legal pluralist perspective: The case of Kampala, Uganda." Habitat International 32 (1):109-20. doi: 10.1016/j.habitatint.2007.08.004.

Nuijten, Monique. 2015. "Political activism and the PAH (Platform of Mortgage Victims) in Spain: the significance of Franz von Benda-Beckmann's work for the study of power, political agency and legal pluralism at the grassroots." The Journal of Legal Pluralism and Unofficial Law 47 (3):476-92. doi: 10.1080/07329113.2015.1113683.

Nuwagaba, Augustus. 1996. "Urbanisation and environmental crisis in a Ugandan city: Implications for environmental management and sustainable development." Eastern Africa Social Science Research Review 12 (1):1-33.

- 2006. "Dualism in Kampala: Squalid slums in a Royal Realm." In African Urban Economies, edited by D F Bryceson and Deborah Potts, 151-. London: Palgrave Macmillan.

Nuwagaba, Augustus, and D Mwesigwa. 1997. "Environmental crisis in peri-urban settlements in Uganda: implications for environmental management and sustainable development." In. Ottawa: IDRC.

Oliver-Smith, A., \& de Sherbinin, A. (2014). Resettlement in the twenty-first century. Forced Migration Review, 45, 23-25.

Oomen, Barbara, and Elif Durmus. 2019. "Cities and plural understandings of human rights: agents, actors, arenas." The Journal of Legal Pluralism and Unofficial Law 51 (2):141-50. doi: 10.1080/07329113.2019.1596731.

Platteau, J-P. 1996. "The evolutionary theory of land rights as applied to sub-Saharan Africa: A critical assessment." Development \& Change 27 (1):29-85.

Rakodi, Carole, and Resetselemang Clement Leduka. 2004. "Informal land delivery processes and access to land for the poor: A comparative study of six African cities." In Informal land delivery processes in African cities, 45. Birmingham: International Development Department, University of Birmingham and Department of Geography, National University of Lesotho.

Republic of Uganda. 2013. "Land Sector Strategy Plan. 2013-2023." In. Kampala: Ministry of Lands, Housing and Urban Development.

Singer, J. W. 2000. Entitlement: The paradoxes of property. New Haven and London: Yale University Press.

UN-Habitat 2013. Flood Risk Assessment, Strategies and Actions for

Improving Flood Risk Management in Kampala. Final Report of Integrated Flood Management Project Kampala. UN-Habitat Cities and Climate Change Initiative.

VanderVelde, Lea S. 1993. "Legal Pluralism and Equal Treatment." The Journal of Legal Pluralism and Unofficial Law 25 (33):91-105. doi: 10.1080/07329113.1993.10756444.

Waters, James J. 2013. "The role of ecosystem services and adaptive capacity in the resilience of poor urban areas." University of East Anglia. 